O. I. Polukarov ${ }^{1}$, Cand. Sc. (Tech.), Assoc. Prof., orcid.org/0000-0003-4260-0330,

N. A. Prakhovnik ${ }^{1}$, Cand. Sc. (Tech.), Assoc. Prof., orcid.org/0000-0003-0821-2166,

Yu. O. Polukarov', Cand. Sc. (Tech.), Assoc. Prof., orcid.org/0000-0002-6261-3991,

O. Ye. Kruzhilko², Dr. Sc. (Tech.), Senior Research

Fellow,

orcid.org/0000-0001-8624-1515,

H. V. Demchuk ${ }^{1}$, Cand. Sc. (Tech.), Assoc. Prof., orcid.org/0000-0003-3939-5516

\title{
STRATIFICATION OF EXPENSES OF INSURANCE FUNDS TO COVER RISK SITUATIONS OF PRODUCTION PROCESS
}

Purpose. To estimate the formation of insurance funds that can be used to solve problems and cover the structural components of countering the financial crisis.

Methodology. In the research, the authors applied the method of simulation modeling, which allowed identifying several scenarios that can be implemented in formation of insurance funds with different coverage for companies of the mining and metallurgical complex. In addition, a technique was used to construct the tree method, which suggests the multivariance of formation of insurance coverage depending on the probability of occurrence of certain events.

Findings. This work provides a comparative analysis of bankruptcy models and ensuring financial stability of the enterprise for the purpose of quality control of manufactured products. The authors of the article have developed a model that can serve as a basis for the formation of intelligent decision-making process at a constant level of risk. The paper indicates that the main factor of risk conditions formation is reduction in the cost of ensuring the safety of production processes, which generates secondary risk in the conditions of enterprises of the mining and metallurgical complex.

Originality. The safety of the production process is determined depending on how significant the financial reserves of the enterprise should be to cover possible losses and, accordingly, the situation when financing of the enterprise will require additional financial flow. In this situation, the current cash flows of the enterprise can be used and the peculiarities of reducing costs for ensuring the safety of the production process are considered. In this work, this aspect is defined as a probabilistic one. Modeling financial stability is carried out with the consideration of the factor of ensuring the proper level of safety of the production process.

Practical value. The data obtained allows predicting payments not only from insurance funds of enterprises, but also from other sources that affect the probability of bankruptcy or deterioration of financial condition of the enterprise.

Keywords: insurance funds, production costs, financial stability, financial crisis, the safety of the production process

Introduction. Based on the results of analysis of the experience of applying methods and models of anti-crisis financial management processes in companies of mining and metallurgical complex, and also taking into account the research objectives and limitations, we can select the methods where the key processes of anti-crisis financial management in the mining and metallurgical companies will be used. We believe that reducing the financial stability of mining and metallurgical complex requires company management primarily to reduce costs or otherwise optimize expenditures [1]. The main ways for such a reduction on the part of management is usually to reduce the cost of ensuring safety of the production process, which in turn contributes to the formation of additional risk [2]. Consequently, we consider the need to develop a model that will take into account the need to stabilize the financial condition of enterprises [3].

The main goals of identifying signs of financial crisis in mining and metallurgical complex companies are to obtain an impartial and accurate result, therefore, high classification and forecasting properties of models are priority. At the same time, it should be kept in mind that obtaining an effective model is possible only if all the limitations, requirements and assumptions of the corresponding method were taken into account [4]. For this reason, high demands to data characteristics often serve as the greatest restriction for application of a certain method in practice.

An essential condition for focusing on obtaining objective result is the need to obtain a fixed structure of the developed

(C) Polukarov O. I., Prakhovnik N.A., Polukarov Yu. O., Kruzhilko O. Ye., Demchuk H. V., 2020 models [5]. Since simulation results are used for decision making, the multiplicity and inconsistency of simulation results may be considered a drawback [6]. In business practice, usually, the use of low complexity methods is required, the structure of which can be interpreted by managers and used not only in identifying signs of financial crisis, but also in responding to and learning from the financial crisis. That is to say, the models of crisis management financial processes must be both transparent and relatively uncomplicated.

Methods. When designing anti-crisis financial management, modeling methods were used that can be directly applied in responding to crisis events. Despite the fact that simulation practice is widely used in general management practice, the experience with using this kind of mathematical methods in the area of crisis management of companies remains rather limited.

Imitation modeling is one of the most effective means for modeling business processes. Within its framework, several groups of methods are distinguished, among which there is discrete event modeling, agent modeling and system dynamics. The main differences between them involve the approach to accounting for the time factor: system dynamics considers time in continuous form; other methods are discrete. Then, discrete event modeling, as it can be understood from the name, is based on transaction events that affect the change in certain resources displayed in diagrams. Agent-based modeling made it possible to build isolated active subsystems (agents) that act in accordance with their own established rules, and, interacting with other agents, shaping behavior of higher-level systems.

The analysis of enterprise management was based on the method of system dynamics using studies of engineering con- 
trol, cybernetics and organizational theory. The first models of system dynamics were associated with stocks management, labor movement, market fluctuations. The main goal of system dynamics models is to obtain a common understanding of the functioning of system at the decision-making stage. For this, an analysis of feedbacks in the system is used, which are presented in the models as feedback loops. Elements of these loops are stocks and flows. Stocks (levels, reservoirs, and others) characterize the accumulation of certain tangible or intangible resources at a certain point in time, while flows demonstrate the speed at which changes in reserves occur.

Using the mathematical apparatus of the method of system dynamics was quite simple including provision for the procedure of addition (subtraction) of flows. That is to say, stocks can be represented as integrals, and flows - as differentials. In the modeling process, differential equations (in case of continuous time), or difference equations (in case of discrete time) were used. Software typically uses numerical integration algorithms, namely Euler's scheme and Runge-Kutta scheme with a constant step and for given initial parameters.

System-dynamic analysis and modeling make an exceptionally effective method for use in crisis management. Among its advantages are: the ability to test effectiveness, flexibility and stability of systems, as well as the ability to build monitoring and detection systems; assistance in establishment of measures (policies) for crisis prevention and crisis response; assessment of management decisions.

Results. Let us generalize the important characteristics of the methods used in modeling of financial crisis management processes (Table 1).

Taking into account the described criteria and characteristics of methods and models, the most acceptable ones for use in the study are as follows:

1. To build models to identify signs of financial crisis: support vector method (high accuracy, low data requirements, fixed structure); decision trees (low data requirements, transparent fixed structure of models, simplicity, medium accuracy) [7]; conditional probability models (high accuracy, transparent fixed structure of models, relative simplicity, medium data requirements) [8].

2. To build models for responding to financial crisis and learning from the crisis: system dynamics (transparent structure, the ability to test alternatives, availability of tools to create training systems).

The modeling process begins with making models to identify signs of financial crisis $[9,10]$. The method of support vectors. The support vector method may be used to classify enter- prises in mining and metallurgical complex [11]. We describe a typical classification problem in terms of the ideas of PAC (Probably Approximately Correct-learning) machine learning theory $[12,13]$. The formal statement of the problem is based on probabilistic assumptions. Let each case $\mathrm{x}$ presented for training and verification be an element of some set $Q$ (provided by the field of Borelian sets) and be generated by some unknown probability distribution $P$ on $Q$. It can also be assumed that the distribution of cases is independent and the same in accordance with $P$.

Each of $\mathrm{x}$ cases has a label - appearance is a sign of belonging to a certain class ( $\mathrm{Li}$ et al. 2013). Class labels form the set $D$ and are defined using unknown function $c \in C$ of the type $x: Q \rightarrow D$ called the concept: $c(x)$ and label $X$. Let hypothesis $h=h_{s}$ be constructed for some random sample $S=\left(\left(x_{1}\right.\right.$, $\left.\left.c\left(x_{1}\right)\right), \ldots,\left(x_{l}, c\left(x_{l}\right)\right)\right)$ generated by distribution $P$, which expresses the belonging of objects $X$ to the classes (subsets of $Q$ ) generated by the unknown concept $C$. In this case, the error of hypothesis $h$ is defined as $\operatorname{err}_{P}(h)=P\{h(x) \neq c(x)\}$.

It is necessary to find such a hypothesis $h$ for which the probability of an event, which consists in the fact that the error $\operatorname{err}_{P}(h)$ is significant, remains small, or it can be argued that the hypothesis $h$ is probably approximately true. The degree of approximation is quantified using the parameter $\varepsilon$ : inequality $\operatorname{err}_{P}(h) \leq \varepsilon$ must be satisfied; the degree of probability is expressed by the level of confidence $\delta$, that is, inequality $\operatorname{err}_{P}(h) \leq$ $\leq \varepsilon$ must be satisfied with a probability of no less than $1-\delta$. Algorithm $A$ reconstructs the class of concepts $C$ using the hypothesis class $H$ if, for an arbitrary concept $c \in C$ and for any probability distribution $P$ on cases $x$, and for arbitrary $\varepsilon \in(0,1 / 2)$ and $\delta \in(0,1 / 2)$, the following is true:

1. Algorithm $A$ receives a training sample in form of input data; the sample consists of random $(x, c(x))$, independently and equally distributed over $\mathrm{p}$, the number of which polynomially depends on $1 / \varepsilon$ and $1 / \delta$.

2. Algorithm $A$ produces function $h$ as the result, for which $\operatorname{err}_{P}(h) \leq \varepsilon$ has a probability of at least $1-\delta$.

In this case, the class of concepts $C$ is PAC-learnable. In the modern statistical theory of machine learning, the formulation of the given problem is widespread without using the concept. Instead, it is assumed that pairs $(x, y)$ of objects $X$ and their markers y are the same and independently distributed in accordance with a certain unknown probability distribution $P$ on the set $Q \times D$. It is assumed that the sample $S=\left(\left(x_{1}, y_{1}\right), \ldots\right.$, $\left.\left(x_{l}, y_{l}\right)\right)$ is generated by a source, the basic assumption about which lies in the fact that for the pairs $(x, y)$, or for the space $Q \times D$, the probability distribution $P$ is given, and the pairs

Table 1

Comparison of the characteristics of methods and models

\begin{tabular}{|l|l|c|c|c|c|c|c|}
\hline \multicolumn{2}{|l|}{ Method } & Accuracy & $\begin{array}{c}\text { Data } \\
\text { Demand }\end{array}$ & $\begin{array}{c}\text { Fixed } \\
\text { structure }\end{array}$ & $\begin{array}{c}\text { Transparent } \\
\text { structure }\end{array}$ & $\begin{array}{c}\text { Possibility of use } \\
\text { Complexity } \\
\text { (Det. detection, } \\
\text { Reg - response, } \\
\text { Tr. }- \text { training) }\end{array}$ \\
\hline \multirow{4}{*}{$\begin{array}{l}\text { Classic Statistical } \\
\text { Methods }\end{array}$} & Single Variable Models & Low & Low & Yes & Yes & Low & Det./Reg. \\
\cline { 2 - 8 } & Index models & Low & Low & Yes & Yes & Low & Det./Reg. \\
\cline { 2 - 9 } & Multiple discriminant analysis & High & High & Yes & Not & Average & Det./Reg. \\
\cline { 2 - 9 } & Conditional Probability Models & High & Average & Yes & Yes & Average & Det./Reg. \\
\hline \multirow{5}{*}{ AI Methods } & Artificial Neural Networks & High & High & Not & Not & High & Det. \\
\cline { 2 - 9 } & Decision trees & Average & Average & Yes & Yes & Low & Det./Reg. \\
\cline { 2 - 9 } & Evolutionary algorithms & Low & Average & Not & Yes & Average & Det./Reg. \\
\cline { 2 - 9 } & Approximate Set Method & Low & Average & Not & Yes & Average & Det./Reg. \\
\cline { 2 - 8 } & Support Vector Method & High & Low & Yes & Not & High & Det \\
\cline { 2 - 8 } & Reasoning from past observations & Average & Low & Yes & Not & Low & Det/Tr. \\
\hline Simulation modeling & System dynamics & Low & Average & - & Yes & Average & Det./Reg/Tr \\
\hline
\end{tabular}


$\left(x_{i}, y_{i}\right)$, forming the sample $S$, are equally and independently distributed. Accordingly, for the set $(Q \times D)^{l}$ the probability distribution is given as $P^{l}=P \times P \times \ldots \times P$.

A classification rule or function (hypothesis) is a function of type $h: Q \rightarrow D$ that divides elements $x_{i} \in X$ into several classes. The function $\mathrm{h}$ can also be called the classifier, or decision rule. In this case, the binary classification $D=\{-1,1\}$ will be considered (presentation option $D=\{0,1\}$ can also be used), and the function is called the indicator function. Then the whole sample $S$ is divided into two subsamples: $S^{+}=\left(\left(x_{i}, y_{i}\right)\right.$ : $\left.: y_{i}=1\right)$ - positive cases and negative cases

$$
h(x)=\left\{\begin{array}{l}
1, f(x)>r \\
-1
\end{array}\right.
$$

Let us describe in more detail the construction of the classifier based on the support vector method. The classification problem based on support vector method is to find the optimal dividing hyperplane in the space of features of high dimension. In this case, optimality is understood as minimization of upper estimates of the probability of generalization error (prediction). In most cases studied classes of observations cannot be separated without any direct mistakes, therefore let us envisage the procedure of constructing a support vector for an undivided case. Let the training sample consist of $N$ pairs $\left(x_{1}, y_{1}\right)$, $\left(x_{2}, y_{2}\right), \ldots,\left(x_{N}, y_{N}\right)$, where $x \in R^{n}, y_{i} \in\{-1,1\}$. The hyperplane is defined as

$$
x: f(x)=x^{T} \beta+b=0,
$$

where $\beta$ is a unit vector $(\|\beta\|=1)$. In this case, the classification rule induced by the function $f(x)$ will be as follows

$$
G(x)=\sin g\left(x^{T} \beta+b\right) .
$$

The function $f(x)$ allows us to get the distance with a sign from the point to hyperplane $f(x)=x^{T} \beta+b=0$. If the classes are shared, we can find the function $f(x)=x^{T} \beta+b$ and $y_{i} f\left(x_{i}>\right.$ $>0 \forall i)$. Hence, it is possible to find a hyperplane that provides the largest boundary between observations and the training sample for classes 1 and -1 . The described problem corresponds to the optimization problem

$$
\max _{\beta, b\|\beta\|=1} M \text {. }
$$

On condition $y_{i}\left(x_{i}^{T} \beta+b\right) \geq M, i-1, \ldots, N$ where the norm restriction $\beta$ is omitted and $M=1 /\|\beta\|$.

The strip, or the border, is located at a distance of $M$ units on both sides of the hyperplane and has a width of $2 M$. It is more convenient to present the described problem in form

$$
\min _{\beta, b}\|\beta\|
$$

provided that $y_{i}\left(x_{i}^{T} \beta+b\right) \geq 1, i=1, \ldots, N$ where the norm $\beta$ restriction is omitted, and $M=1 /\|\beta\|$. There are two ways in which we can modify the boundaries of the shared case

$$
y_{i}\left(x_{i}^{T} \beta+b\right) \geq M-\xi_{i},
$$

or

$$
y_{i}\left(x_{i}^{T} \beta+b\right) \geq M\left(1-\xi_{i}\right),
$$

where $\forall i \xi_{i} \geq 0, \sum_{i=1}^{N} \xi_{i} \leq C$ (C is some constant).

The value $\xi_{i}$ in restriction $y_{i}\left(x_{i}^{T} \beta+b\right) \geq M\left(1-\xi_{i}\right)$ is proportional to the amount by which the predictions using hyperplane $f\left(x_{i}\right)=x_{i}^{T} \beta+b$ "enter" on the wrong side. So, by limiting the amount $\sum \xi_{i}$, the total relative spacing of incorrect predictions is limited. The classification is false if $\xi_{i}>1$, therefore, limiting the sum $\sum \xi_{i}$ to a certain value of $K$ allows us to limit the number of learning errors $K$. In the shared case, we can omit the restrictions on the norm $\beta$ by defining $M=1 /\|\beta\|$ and writing the initial optimization problem in the equivalent form

$$
\min \|\beta\|,
$$

according to conditions. From the formed problem it follows that observation

$$
\left\{\begin{array}{l}
y_{i}\left(x_{i}^{T} \beta+b\right) \geq 1-\xi_{i} \forall i \\
\xi_{i} \geq 0, \sum \xi_{i} \leq C
\end{array}\right.
$$

within the class does not play much role in determining the constraints (this significantly distinguishes the support vector method from discriminant analysis). The solution to this optimization problem is done using the Lagrange multipliers. To simplify the calculations, it is appropriate to use the equivalent form of the problem

$$
\min _{\beta, b} \frac{1}{2}\|\beta\|^{2}+C \sum_{i=1}^{N} \xi_{i}
$$

In conditions $\xi_{i} \geq 0, y_{i}\left(x_{i}^{T} \beta+b\right) \geq 1-\xi_{i} \forall i$ where $C$ is a constant (in the shared case $C=\infty$ ). The Lagrange function has the form

$$
L_{P}=\frac{1}{2}\|\beta\|^{2}+C \sum_{i=1}^{N} \xi_{i}-\sum_{i=1}^{N} \alpha_{i}\left[y_{i}\left(x_{i}^{T} \beta+b\right)-\left(1-\xi_{i}\right)\right]-\sum_{i=1}^{N} \mu_{i} \xi_{i},
$$

and should be minimized by $\beta, b, \xi_{i}$. Equating the corresponding derivatives to zero, we obtain

$$
\begin{gathered}
\beta=\sum_{i=1}^{N} \alpha_{i}, y_{i}, x_{i} ; \\
b=\sum_{i=1}^{N} \alpha_{i}, y_{i} ; \\
\alpha_{i}=C-\mu_{i} \forall i,
\end{gathered}
$$

where $\alpha_{i}, \mu_{i}, \xi_{i} \geq 0 \forall i$. The dual optimization problem has the form

$$
L_{D}=\sum_{i=1}^{N} \alpha_{i}-\frac{1}{2} \sum_{i=1}^{N} \sum_{i^{\prime}=1}^{N} \alpha_{i}, \alpha_{i^{\prime}} y_{i} y_{i^{\prime}} x_{i}^{T} x_{i^{\prime}} .
$$

It represents the lower boundary of the objective function. Maximization $L_{D}$ under conditions $0 \leq \alpha_{i} \leq C$ and $\sum_{i=1}^{N} \alpha_{i} y_{i}=0$. In addition, restrictions should be included in accordance with the conditions of Karush-Kuna-Tucker

$$
\begin{gathered}
\alpha_{i}\left(y_{i}\left(x_{i}^{T} \beta+b\right)-\left(1-\xi_{i}\right)\right)=0 ; \\
\mu_{i}, \xi_{i}=0 ; \\
y_{i}\left(x_{i}^{T} \beta+b\right)-\left(1-\xi_{i}\right) \geq 0,
\end{gathered}
$$

for $i=1, \ldots, N$. The above equations uniquely characterize the solutions of direct and dual problems. The solution for $\beta$ is written as follows

$$
\hat{\beta}=\sum_{i=1}^{N} \hat{\alpha}_{i} y_{i} x_{i},
$$

only for those $i$, which are corresponding to $y_{i}\left(x_{i}^{T} \beta+b\right)$ $-\left(1-\xi_{i}\right) \geq 0, \quad\left(\hat{\alpha}_{i} \neq 0\right)$. These observations are called reference vectors, since $\hat{\beta}$ is completely described by them. Among the reference vectors, some observations are placed directly on the edge of the border $\left(\hat{\xi}_{i}=0 ; 0 \leq \alpha_{i} \leq C\right)$, and others - not $\left(\hat{\xi}_{i}>0 ; \alpha_{i}=C\right)$. 
In the described procedure, $C$ acts as a parameter, the setting of which allows us to change the "tolerance" of the border, and, consequently, regulate the probability of retraining the reference vector model. Nonlinear constraints of the original feature space can be turned into linear constraints in the extended feature space. They permit to obtain high accuracy of separation. Choosing basic functions $h_{m}(x) m=1, \ldots M$, the procedure for searching support vectors can be reduced to the previous one. Using input features, $h\left(x_{i}\right)=\left(h_{1}\left(x_{i}\right), h_{2}\left(x_{i}\right), \ldots\right.$, $\left.h_{M}\left(x_{i}\right)\right), i=1, \ldots, N$, nonlinear function $\hat{f}(x)=h(x)^{T} \hat{\beta}+\hat{b}$ can be built. Furthermore, the classifier function, as in previous case, has the form $\hat{G}(x)=\operatorname{sign}(\hat{f}(x))$.

The optimization problem can be submitted in a special form, which involves using of scalar product of input features (this is done by the transformation of vectors of input features $\left.h\left(x_{i}\right)\right)$. In this case, the dual form of Lagrange function has the form

$$
L_{D}=\sum_{i=1}^{N} \alpha_{i}-\frac{1}{2} \sum_{i=1}^{N} \sum_{i^{\prime}=1}^{N} \alpha_{i} \alpha_{i^{\prime}} y_{i} y_{i^{\prime}}\left\langle h\left(x_{i}\right), h\left(x_{i^{\prime}}\right)\right\rangle .
$$

The solution can be represented in the form

$$
f(x)=h(x)^{T} \beta+b \sum_{i=1}^{N} \alpha_{i} y_{i}\left\langle h(x), h\left(x_{i}\right)\right\rangle+b .
$$

Using the given value, $\alpha_{i}, b$ we can calculate by solving the above expression $y_{i} f\left(x_{i}\right)=1$ for any $x_{i}$ for which $0<\alpha_{i}<C$. Transformation $h(x)$ does not need to be defined with a kernel function

$$
K\left(x, x^{\prime}\right)=\left\langle h(x), h\left(x^{\prime}\right)\right\rangle,
$$

with the help of which the scalar values are calculated in the transformed feature space. The function $K$ must be symmetric, positive definite (partially or completely). For example, we can use the polynomial function of the kernel of the second degree with two input features $X_{1}$ and $X_{2}$. Then

$$
\begin{gathered}
K\left(X, X^{\prime}\right)=\left(1+\left\langle X, X^{\prime}\right\rangle\right)^{2}=\left(1+X_{1} X_{1}^{\prime}+X_{2} X_{2}^{\prime}\right)^{2}= \\
=1+2 X_{1} X_{1}^{\prime}+2 X_{2} X_{2}^{\prime}+\left(X_{1} X_{1}^{\prime}\right)^{2}+\left(X_{2} X_{2}^{\prime}\right)^{2}+2 X_{1} X_{1}^{\prime} X_{2} X_{2}^{\prime} .
\end{gathered}
$$

That is, $M=6$ and, if we place $\mathrm{h}_{1}(X)=1, h_{2}(X)=\sqrt{2} X_{1}$, $h_{3}(X)=\sqrt{2} X_{2}, h_{4}(X)=X_{1}^{2}, h_{5}(X)=X_{2}^{2}, h_{6}(X)=\sqrt{2} X_{1} X_{2}$, the function $K\left(X, X^{\prime}\right)=\left\langle h(X), h\left(X^{\prime}\right)\right\rangle$. Then the solution to the optimization problem can be written as

$$
\hat{f}(x)=\sum_{i=1}^{N} \hat{\alpha}_{i} y_{i} K\left(x, x_{i}\right)+\hat{b} .
$$

The high value of the parameter $C$ does not allow for large positive values $\xi_{i}$, by increasing probability by adjustment of sample model under study. On the other hand, a low value of $C$ decreases the value $\|\beta\|$, and consequently makes the function more equal. In the modeling process using the support vector method, we shell use the software RapidMiner Support
Vector Machine method. When building models, it is necessary to determine the type of the core function of support vectors, as well as corresponding parameters. The theory of choosing the optimal value of the parameters of kernel functions for the support vector method is limited; therefore, in applied research, their enumeration is normally used.

To assess the accuracy of the models, we are going to use the error matrix for typical classification problem. The bankrupt class corresponds to the value of the label " 1 ", the class of financially healthy companies - " 0 ". Table 2 shows the most common indicators of the classification properties of models - accuracy, sensitivity and specificity, as well as formulas for their calculation.

In the modeling process, we are going to apply the procedure of 10 -fold cross-validation. At the same time, the existing sample will be randomly divided into 10 subsamples, 9 of which become training ones, and one - the control sample; the process will be repeated 10 times. This allows us to get average simulation results and reduce the risk of relearning. It is also important that the random formation of subsamples occurs using stratified formation of subsamples, which allows us to take into account the imbalances between classes. In addition to using cross-validation, the modeling process also includes built-in data scaling and value balancing for incorrect classification of disproportionate classes.

In order to prepare data for the simulation sampling processing was performed consisting of encoding outcasts and missing data again. It is worth noting that the simple exclusion of companies with a significant number of data gaps and limit values of indicators is not reasonable. That is why indicators whose values were outside the $10^{\text {th }}$ and $90^{\text {th }}$ percentiles were identified as outcasts. At the same time, outcasts were evaluated separately within the groups of financially healthy enterprises of the mining and metallurgical complex and enterprises of the mining and metallurgical complex that ceased operations in order to avoid data averaging [14]. If the identified outcast had a value less than the $10^{\text {th }}$ percentile, its value was replaced by the value of percentile; if the outcast was above the $90^{\text {th }}$ percentile, its value was limited to this percentile. Data gaps, which were mainly associated with the uncertainty of indicator values (division of zero by zero), were replaced by the median.

It can be stated that the relationship of signs with the indicator of well-defined class has changed after elimination of outcasts, because none of the ten most relevant variables coincides. Due to the fact that there is no certainty that the elimination of outcasts eliminated some of the important information on the activities of the mining and metallurgical complex, we will try to form sets of uncorrelated variables based on both lists of indicators obtained. Calculate pairwise correlations between the indicators for both signs of lists (Table 3).

We will perform modeling on the basis of the generated sets of variables with kernel functions - a scalar multiplication $K\left(x_{i}, x_{j}\right)=x_{i} x_{j}\left(x_{i}, x_{j}\right.$ is a pair of attributes), a polynomial $K\left(x_{i}\right.$, $\left.x_{j}\right)=\left(x_{i} x_{j}+1\right)^{d}(\mathrm{~d}-$ degree of a polynomial $)$, a radial basis function $K\left(x_{i}, x_{j}\right)=e^{\gamma\left\|x_{i}-x_{j}\right\|^{2}}(\gamma>0$ is free parameter). For scalar product we will vary the values of $C$ and parameters (the first of them shows the ratio between the complexity of the

Table 2

Error matrix

\begin{tabular}{|l|l|l|}
\hline \multirow{2}{*}{\multicolumn{1}{|c|}{ Classification }} & \multicolumn{2}{c|}{ Observation } \\
\cline { 2 - 3 } & \multicolumn{1}{c|}{0 (financially healthy company) } & \multicolumn{1}{c|}{1 (bankrupt, crisis company) } \\
\hline 0 (financially healthy company) & $a$ (true negative) & $b$ (type I error, false negative) \\
\hline 1 (bankrupt, crisis company) & $c$ (type II error, false positive) & $d$ (true positive) \\
\hline Classification accuracy indicator by classes & Specificity $(a /(a+c)) 100 \%$ & Sensitivity $(\mathrm{d} /(\mathrm{b}+\mathrm{d})) 100 \%$ \\
\hline General Accuracy Model & Accuracy $((\mathrm{a}+\mathrm{d}) /(\mathrm{a}+\mathrm{b}+\mathrm{c}+\mathrm{d})) 100 \%$ \\
\hline
\end{tabular}


Paired correlations between indicators

\begin{tabular}{|c|c|c|c|c|c|c|c|c|c|c|}
\hline Indicators & Indicators & & & & & & & & & \\
\hline & {$[C+C F I+R] / T A$} & $\mathrm{CFO} / \mathrm{S}$ & $E / S$ & \multicolumn{2}{|c|}{$E / T L$} & $I I /[C+C F I+L T F I]$ & $N S / T A$ & $Q R$ & $T L / T A$ & $W C / S$ \\
\hline \multicolumn{11}{|c|}{ Original sample } \\
\hline$[C+C F I+R] / T A$ & 1.000 & 0.044 & -0.007 & \multicolumn{2}{|c|}{0.077} & 0.193 & 0.231 & 0.182 & 0.196 & 0.090 \\
\hline$C F O / S$ & 0.044 & 1.000 & -0.465 & \multicolumn{2}{|c|}{-0.075} & 0.071 & 0.061 & -0.009 & 0.058 & -0.521 \\
\hline$E / S$ & -0.007 & -0.465 & 1.000 & \multicolumn{2}{|c|}{0.071} & -0.059 & -0.294 & 0.020 & 0.146 & 0.908 \\
\hline$E / T L$ & 0.077 & -0.075 & 0.071 & \multicolumn{2}{|c|}{1.000} & -0.013 & -0.172 & 0.943 & -0.212 & 0.071 \\
\hline$I I /[C+C F I+L T F I]$ & 0.193 & 0.071 & -0.059 & \multicolumn{2}{|c|}{-0.013} & 1.000 & 0.101 & 0.027 & 0.207 & -0.043 \\
\hline$N S / T A$ & 0.231 & 0.061 & -0.294 & \multicolumn{2}{|c|}{-0.172} & 0.101 & 1.000 & -0.101 & 0.163 & -0.155 \\
\hline$Q R$ & 0.182 & -0.009 & 0.020 & \multicolumn{2}{|c|}{0.943} & 0.027 & -0.101 & 1.000 & -0.124 & 0.059 \\
\hline$T L / T A$ & 0.196 & 0.058 & 0.146 & \multicolumn{2}{|c|}{-0.212} & 0.207 & 0.163 & -0.124 & 1.000 & 0.154 \\
\hline$W C / S$ & 0.090 & -0.521 & 0.908 & \multicolumn{2}{|c|}{0.071} & -0.043 & -0.155 & 0.059 & 0.154 & 1.000 \\
\hline \multicolumn{11}{|c|}{ Processed selection } \\
\hline Indicators & {$[C+C F I+R] / T A$} & $C / T A$ & $C L / T A$ & $E / T A$ & $G P / E$ & $\mathrm{CFO}$ & $N I / T A$ & $R E / T A$ & $T D / T A$ & $P R$ \\
\hline$[C+C F I+R]$ Growth & 1.000 & 0.083 & 0.273 & -0.251 & 0.100 & 0.132 & 0.111 & 0.001 & -0.016 & 0.042 \\
\hline$C / T A$ & 0.083 & 1.000 & 0.097 & -0.426 & 0.629 & -0.046 & 0.109 & 0.086 & -0.003 & 0.074 \\
\hline$C L / T A$ & 0.273 & 0.097 & 1.000 & -0.749 & 0.245 & -0.005 & -0.128 & -0.095 & 0.212 & 0.009 \\
\hline$E / T A$ & -0.251 & -0.426 & -0.749 & 1.000 & -0.648 & 0.025 & 0.059 & 0.074 & -0.261 & -0.118 \\
\hline$G P / E$ & 0.100 & 0.629 & 0.245 & -0.648 & 1.000 & 0.006 & 0.173 & 0.027 & 0.087 & 0.166 \\
\hline CFO & 0.132 & -0.046 & -0.005 & 0.025 & 0.006 & 1.000 & 0.107 & 0.093 & 0.047 & 0.067 \\
\hline$N I / T A$ & 0.111 & 0.109 & -0.128 & 0.059 & 0.173 & 0.107 & 1.000 & 0.564 & 0.022 & 0.138 \\
\hline$R E / T A$ & 0.001 & 0.086 & -0.095 & 0.074 & 0.027 & 0.093 & 0.564 & 1.000 & -0.007 & 0.094 \\
\hline$T D / T A$ & -0.016 & -0.003 & 0.212 & -0.261 & 0.087 & 0.047 & 0.022 & -0.007 & 1.000 & -0.020 \\
\hline$P R$ & 0.042 & 0.074 & 0.009 & -0.118 & 0.166 & 0.067 & 0.138 & 0.094 & -0.020 & 1.000 \\
\hline
\end{tabular}

model and the error value, the second - determines the level of accuracy of the approximate function for imposing additional forfeit $\left(y_{i}\left(x^{T} \beta+b\right) \geq 1-\xi_{i}-\varepsilon, \xi_{i} \geq 0, \varepsilon \geq 0\right)$; the greater is $\varepsilon$, the smaller are the reference vectors in the model). Table 4 demonstrates the simulation results.

We are going to build models using a complex algorithm for selecting features, namely, the algorithm of minimum redundancy - maximum relevance with additional consider-

Table 4

Characteristics of models of support vectors built on sets of signs No. 1-4

\begin{tabular}{|c|c|c|c|c|}
\hline $\begin{array}{c}\text { Set of } \\
\text { attributes, } \\
\text { No. }\end{array}$ & $\begin{array}{l}\text { Kernel function } \\
\text { parameters }\end{array}$ & 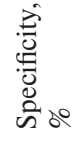 & 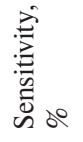 & 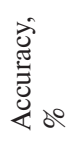 \\
\hline \multirow[t]{3}{*}{1} & $\begin{array}{l}\text { Scalar multiplication, } \\
C=0.1, \varepsilon=0.1\end{array}$ & 92.04 & 53.85 & 89.12 \\
\hline & $\begin{array}{l}\text { Polynomial, } \\
C=1, d=3\end{array}$ & 88.54 & 80.77 & 87.94 \\
\hline & $\begin{array}{l}\text { Radial basis function, } \\
C=1, \gamma=0.25\end{array}$ & 90.45 & 80.77 & 89.71 \\
\hline 2 & $\begin{array}{l}\text { Radial basis function, } \\
C=5, \gamma=0.2\end{array}$ & 92.04 & 80.77 & 91.18 \\
\hline 3 & $\begin{array}{l}\text { Radial basis function, } \\
C=0.1, \gamma=0.1\end{array}$ & 58.92 & 88.46 & 61.18 \\
\hline 4 & $\begin{array}{l}\text { Radial basis function, } \\
C=1, \gamma=0.1\end{array}$ & 71.02 & 92.31 & 72.65 \\
\hline
\end{tabular}

ation for the change in the importance of characteristics between years. At the same time, we will use processed samples, because previous modeling results indicated high performance of the models in which data with remote outcasts were used. The method that was used consists in simultaneously taking into account both the relevance of the features and the relationship between them. The method of minimum redundancy - maximum relevance involves a sequential search (addition)attribute in the set $\mathrm{S}$ according to the criterion

$$
\max _{z_{i} \in \Omega_{s}}\left[F\left(z_{i}, y\right)-\frac{1}{|S|} \sum_{z_{i} \in S}\left|c\left(z_{i}, z_{j}\right)\right|\right],
$$

where $z_{i}$ and $z_{j}$ are the $i^{\text {th }}$ and $j^{\text {th }}$ attributes; y is the class label; $\Omega_{S}$ is the initial set of attributes from which already selected attributes are removed; $F\left(z_{i}, y\right)$ is a measure of relevance; is the power of the set of selected features; $\left|c\left(z_{i}, z_{j}\right)\right|$ is the absolute value of the pairwise measure of redundancy of the current attribute with the already selected ones. In case of continuous distribution of attribute values and the nominal class label, F-statistics are used as a measure

$$
F=\left(z_{i}, y\right)=\left[\sum_{k} n_{k}\left(\bar{z}_{k}\right)-\bar{z} /(K-1)\right] / \sigma^{2},
$$

where $n_{k}$ is the size of the class $\mathrm{k} ; \bar{z}_{k}$ is the average value in the $k^{\text {th }}$ class; $z_{i}$ is the average value of the attribute $z_{i} ; \sigma^{2}=$ $=\left(\sum_{k}\left(n_{k}-1\right) \sigma_{k}^{2}\right) /(n-K)$ is general variation $\left(\left(\sigma_{k}^{2}\right.\right.$ is variation of class $k$ ); $K$ is the number of classes.

Table 5 shows the results of the selection of features by the method of minimum redundancy - maximum relevance. 
Table 5 parameters of selected models for each of the sets of variables

Definition of a list of features (variables) using the method of minimum redundancy - maximum relevance

\begin{tabular}{|c|c|}
\hline \multicolumn{2}{|c|}{ Year } \\
\hline 2018 & 2019 \\
\hline$[C+C F I+R] / S$ & {$[C+C F I+R] / S$} \\
\hline$C / C L$ & $C / C L$ \\
\hline$C A / S$ & $E B I T / T A$ \\
\hline$E G r$ & $E / T L$ \\
\hline$G R G r$ & $F P G r$ \\
\hline$[C+C F I+R] / N I R$ & {$[C+C F I+R] / N I R$} \\
\hline$N I / S$ & $N I / S$ \\
\hline$T D / T A$ & $Q R$ \\
\hline$W C / S$ & $W C / S$ \\
\hline$P R$ &
\end{tabular}

are given in Table 10.

As it can be seen from Table 10, the application of super discretization of the class of enterprises of the mining and metallurgical complex in the sample allowed us to obtain reference vector models with the best classification accuracy indicators. The effect of sub-discretization turned out to be ambiguous: there was some deterioration in the characteristics of the models in the first four sets of variables; nevertheless, in the rest sets, an increase in overall accuracy was obvious. Though, rather high values of the parameter $C$ may indicate the probability of retraining models on sets of variables.

Conclusions. The constructed models of support vectors demonstrate high classification and predictive accuracy.

The use of improved feature selection algorithm made it possible to obtain models with the best classification characteristics, while sub-discretization and super-discretization of classes helped to increase the levels of sensitivity and overall accuracy in most models.

Paired correlations between indicators after data processing

\begin{tabular}{|c|c|c|c|c|c|c|c|}
\hline \multicolumn{7}{|c|}{ Indicator } \\
\hline Indicator & {$[C+C F I+R] / S$} & $C / C L$ & $G P G r$ & {$[C+C F I+R] / N I R$} & \multicolumn{1}{|c|}{$N I / S$} & $W S / S$ \\
\hline \multicolumn{7}{|c|}{2018} \\
\hline$[C+C F I+R] / S$ & 1.000 & -0.118 & -0.129 & -0.002 & -0.425 & 0.916 \\
\hline$C / C L$ & -0.118 & 1.000 & 0.210 & -0.133 & 0.053 & -0.136 \\
\hline$G P G r$ & -0.129 & 0.210 & 1.000 & -0.119 & 0.100 & -0.149 \\
\hline$[C+C F I+R] / N I R$ & -0.002 & -0.133 & -0.119 & 1.000 & -0.033 & 0.002 \\
\hline$N I / S$ & -0.425 & 0.053 & 0.100 & -0.033 & 1.000 & -0.499 \\
\hline$W C / S$ & 0.916 & -0.136 & -0.149 & 0.002 & -0.499 & 1.000 \\
\hline$[C+C F I+R] / S$ & 1.000 & -0.153 & -0.162 & 0.769 & -0.339 & 0.835 \\
\hline$C / C L$ & -0.153 & 1.000 & 0.119 & -0.116 & 0.083 & -0.204 \\
\hline$G P G r$ & -0.162 & 0.119 & 1.000 & -0.082 & 0.165 & -0.138 \\
\hline$[C+C F I+R] / N I R$ & 0.769 & -0.116 & -0.082 & 1.000 & -0.210 & 0.552 \\
\hline$N I / S$ & -0.339 & 0.083 & 0.165 & -0.210 & 1.000 & -0.415 \\
\hline$W C / S$ & 0.835 & -0.204 & -0.138 & 0.552 & -0.415 & 1.000 \\
\hline
\end{tabular}

As it can be seen from Table 5, among the 10 most important attributes in two years, there are 6 joint pairs. Make sure that there are no high pair correlations between the attributes. Table 6 shows the correlation matrix for the indicated features

There are high pair correlations between the selected indicators. The indicator $W C / S$ is present in the largest number of correlated pairs $N I / S$ have high correlations with other indicators. Table 7 shows additional sets of uncorrelated variables for modeling. Table 8 shows the simulation results based on a set of indicators No. 5-7 using the polynomial and radial basis functions of the kernel.

Models constructed on the basis of sets of attributes determined by the method of minimum redundancy - maximum relevance have better classification characteristics than models based on sets No. 1-3. Given the disproportionality of the classes of insurers, we apply and compare the procedures of super-discretization and sub- discretization to the sample and analyze the changes in the characteristics of the reference vector models. In this case, we use the radial basis function of the kernel, and also use the Optimize parameters (Grid) software function, which allows us to iterate over the selected parameters within certain limits and get the best model from the position of the accuracy criterion. Parameters and their boundaries are given in Table 9. The classification characteristics and
Table 7

Sets of features (variables) for modeling

\begin{tabular}{|c|c|}
\hline Set, No. & Indicators \\
\hline 5 & {$[C+C F I+R] / S ; C / C L ; G P G r ;[C+C F I+R] / N I R$} \\
\hline 6 & $\mathrm{C} / \mathrm{CL} ; \mathrm{GPGr} ;[C+C F I+R] / N I R ; N I / S$ \\
\hline 7 & $C / C L ; G P r ;[C+C F I+R] / N I R ; W C / S$ \\
\hline
\end{tabular}

Table 8

Characteristics of models of support vectors built on sets of indicators No. 5-7

\begin{tabular}{|c|c|c|c|c|}
\hline 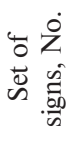 & Kernel function parameters & $\begin{array}{l}\stackrel{\overrightarrow{0}}{0} \\
\stackrel{0}{0} \\
\tilde{\mathscr{D}} \\
\text { के jo }\end{array}$ & 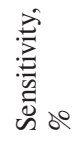 & 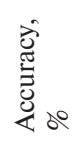 \\
\hline \multirow[t]{2}{*}{5} & Polynomial, $C=5, d=0.5$ & 84.39 & 96.15 & 85.29 \\
\hline & Radial basis function, $C=1, \gamma=1.25$ & 90.13 & 96.15 & 90.59 \\
\hline 6 & Radial basis function, $C=1, \gamma=0.75$ & 87.58 & 96.15 & 88.24 \\
\hline 7 & Radial basis function, $C=1, \gamma=0.75$ & 89.17 & 96.15 & 89.71 \\
\hline
\end{tabular}


Characteristics of the parameter search function

\begin{tabular}{|c|c|c|c|c|}
\hline Parameter & $\begin{array}{c}\text { Minimum } \\
\text { values }\end{array}$ & $\begin{array}{c}\text { Maximum } \\
\text { values }\end{array}$ & $\begin{array}{c}\text { Number } \\
\text { of steps }\end{array}$ & Scale \\
\hline$\gamma$ & 0.1 & 5 & 49 & linear \\
\hline$C$ & 0.001 & 10.000 & 7 & logarithmic \\
\hline
\end{tabular}

Table 10

Classification characteristics and parameters of the selected models of support vectors

\begin{tabular}{|c|c|c|c|c|}
\hline \multirow[b]{2}{*}{ Sample } & \multirow[b]{2}{*}{$\begin{array}{l}\text { A set of features, type and } \\
\text { parameters of the kernel } \\
\text { function }\end{array}$} & \multicolumn{3}{|c|}{ Accuracy indicators } \\
\hline & & 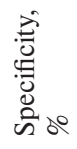 & 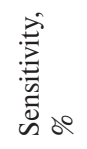 & 兽 \\
\hline \multirow{7}{*}{ 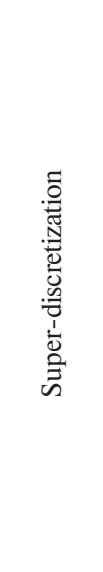 } & $\begin{array}{l}\text { No. } 1 \text {, radial basis function, } \\
\gamma=2.8, C=10000\end{array}$ & 99.04 & 100.00 & 99.52 \\
\hline & $\begin{array}{l}\text { No. 2, radial basis function, } \\
\gamma=4.6, C=100\end{array}$ & 98.73 & 100.00 & 99.36 \\
\hline & $\begin{array}{l}\text { No. } 3 \text {, radial basis function, } \\
\gamma=4.6, C=10\end{array}$ & 93.31 & 100.00 & 96.65 \\
\hline & $\begin{array}{l}\text { No. } 4 \text {, radial basis function, } \\
\gamma=4, C=10000\end{array}$ & 96.50 & 100.00 & 98.25 \\
\hline & $\begin{array}{l}\text { No. } 5 \text {, radial basis function, } \\
\gamma=2, C=10000\end{array}$ & 98.41 & 100.00 & 99,20 \\
\hline & $\begin{array}{l}\text { No. 6, radial basis function, } \\
\gamma=4.4, C=10000\end{array}$ & 98.41 & 100.00 & 99,20 \\
\hline & $\begin{array}{l}\text { No. } 7, \text { radial basis function, } \\
\gamma=3.1, C=100\end{array}$ & 98.73 & 100.00 & 99.36 \\
\hline \multirow{7}{*}{ 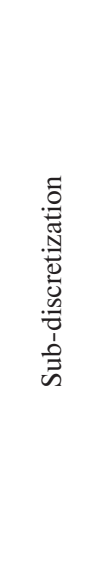 } & $\begin{array}{l}\text { No. 1, radial basis function, } \\
\gamma=2.8, C=10000\end{array}$ & 76.92 & 80.77 & 78.85 \\
\hline & $\begin{array}{l}\text { No. 2, radial basis function, } \\
\gamma=4.6, C=100\end{array}$ & 84.62 & 73.08 & 78.85 \\
\hline & $\begin{array}{l}\text { No. } 3 \text {, radial basis function, } \\
\gamma=4.6, C=10\end{array}$ & 53.85 & 92.31 & 73.08 \\
\hline & $\begin{array}{l}\text { No. } 4 \text {, radial basis function, } \\
\gamma=4, C=10000\end{array}$ & 80.77 & 73.08 & 76.92 \\
\hline & $\begin{array}{l}\text { No. } 5 \text {, radial basis function, } \\
\gamma=2.0, C=10000\end{array}$ & 96.15 & 100.00 & 98.08 \\
\hline & $\begin{array}{l}\text { No. 6, radial basis function, } \\
\gamma=4.4, C=10000\end{array}$ & 96.15 & 100.00 & 98.08 \\
\hline & $\begin{array}{l}\text { No. } 7 \text {, radial basis function, } \\
\gamma=3.1, C=100\end{array}$ & 96.15 & 100.00 & 98.08 \\
\hline
\end{tabular}

The best models among the constructed ones in terms of accuracy were: the models based on the initial sets of variables - a reference vector model using a set of features No. 7 .

Another difference from the previous method is that when constructing decision trees, the relevant characteristics are automatically determined, thus the procedure for their preliminary selection is optional. Nonetheless, in this study, decision trees will be built on the previously proposed sets of variables in order to compare the results of different models.

\section{References.}

1. Zuo, J., Zhao, Z., Xia, B., Zillante, G., \& Pan, Z.-Y. (2015). Sustainability reporting in construction contractors. In: D. Yang \& Y. Qian (Eds.), Proceedings of the $18^{\text {th }}$ International Symposium on Advancement of Construction Management and Real Estate, (pp. 341-348). Berlin: Springer Berlin Heidelberg. https://doi.org/10.1007/978-3-642-44916-1_34.
2. Ayres, R. U. (2017). Gaps in mainstream economics: energy, growth, and sustainability. In S. Shmelev (Ed.), Green Economy Reader: Lectures in Ecological Economics and Sustainability, (pp. 39-53). Cham: Springer International Publishing. https://doi.org/10.1007/978-3-319-38919-6_3.

3. Shatokha, V. (2016). The sustainability of the iron and steel industries in Ukraine: challenges and opportunities. Journal of Sustainable Metallurgy, 2(2), 106-115.https://doi.org/10.1007/ s40831-015-0036-2.

4. Chattopadhyay, S., \& Chattopadhyay, D. (2019). Coal and other mining operations: role of sustainability. In R. A. Meyers (Ed.), Encyclopedia of Sustainability Science and Technology, (pp. 1-25). New York: Springer New York. https://doi. org/10.1007/978-1-4939-2493-6 864-4.

5. Flôres, R. G. (2019). A sustainable CSR instrument for the Brazilian mining sector. In C. Stehr, N. Dziatzko, \& F. Struve (Eds.), Corporate Social Responsibility in Brazil: The Future is Now, (pp. 347-366). Cham: Springer International Publishing. https://doi.org/10.1007/978-3-319-90605-8 17.

6. Seshan, A., \& Gorain, B. K. (2016). An integrated mining and metallurgical enterprise enabling continuous process optimization. In V. I. Lakshmanan, R. Roy, \& V. Ramachandran (Eds.), Innovative Process Development in Metallurgical Industry: Concept to Commission, (pp. 203-242). Cham: Springer International Publishing. https://doi.org/10.1007/978-3-31921599-0_11.

7. Rachwał, M., Wawer, M., Magiera, T., \& Steinnes, E. (2017). Integration of soil magnetometry and geochemistry for assessment of human health risk from metallurgical slag dumps. Environmental Science and Pollution Research, 24(34), 26410-26423. https://doi.org/10.1007/s11356-0170218-5.

8. Sozinova, A.A., Burtseva, T.A., Fokina, O.V., Grabar, A. A., \& Tufyakova, E.S. (2019). The concept of industrial enterprises' economic development amid the global financial and economic crisis. In E. G. Popkova (Ed.), The Future of the Global Financial System: Downfall or Harmony, (pp. 1085-1093). Cham: Springer International Publishing. https://doi.org/10.1007/978-3-030-00102-5 114.

9. Kaufman, B. (2018). Anthropology of metallurgical design: a survey of metallurgical traditions from hominin evolution to the industrial revolution. In B. Kaufman \& C. L. Briant (Eds.), Metallurgical Design and Industry: Prehistory to the Space Age, (pp. 1-70). Cham: Springer International Publishing. https:// doi.org/10.1007/978-3-319-93755-7_1.

10. Storozh, Ya., Kruzhilko, O., Maystrenko, V., \& Polukarov, O. (2018). Information and analytical support improvement for production risk assessment. In Resources and Resource-Saving Technologies in Mineral Mining and Processing Industry: Multi-Authored: monograph, (pp. 16-37). Petrosani: Universitas Publishing.

11. Geng, Y., Liu, Z., Xue, B., Dong, H., Fujita, T., \& Chiu, A. (2015). Emergy-based assessment on industrial symbiosis: a case of Shenyang economic and technological development zone. Environmental Science and Pollution Research, 21(23), 13572-13587. https://doi.org/10.1007/s11356-0143287-8.

12. Intima, D. P. (2017). Sampling plan for quality monitoring of suppliers of the sanitation sector. Periodico Tche Quimica, 14(27), 39-43.

13. da Silva, F.J., \& Gouveia, R. M. (2020). Practices on cleaner production and sustainability. In Cleaner Production: Toward a Better Future, (pp. 247-280). Cham: Springer International Publishing. https://doi.org/10.1007/978-3-03023165-1_7.

14. Gendler, S. G., Grishina, A. M., \& Samarov, L. Y. (2019). Assessment of the labour protection condition in the vertically integrated coil companies on the basis of risk-based approach to analysis of industrial injuries. In Innovation-Based Development of the Mineral Resources Sector: Challenges and Prospects $-11^{\text {th }}$ conference of the Russian-German Raw Materials, 
(pp. 507-514). Routledge, Potsdam. Retrieved from https:// www.routledge.com/Innovation-Based-Development-ofthe-Mineral-Resources-Sector-Challenges/Litvinenko/p/ book/9780367077266.

\section{Стратифікація витрат страхових фондів на покриття ризикових ситуацій виробничого процесу}

\author{
О. І. Полукаров ${ }^{1}$, Н.А. Праховнік ${ }^{1}$ Ю. О. Полукаров ${ }^{1}$, \\ О. Є. Кружилко ${ }^{2}$, Г. В. Демчук ${ }^{1}$
}

1 - Національний технічний університет України «Київський політехнічний інститут імені Ігоря Сікорського», м. Київ, Україна, e-mail: polukarov@kpi.com.de

2 - Державна установа «Національний науково-дослідний інститут промислової безпеки та охорони праці», м. Київ, Україна

Мета. Оцінка порядку формування страхових фондів, що можуть застосовуватися для вирішення проблем і покриття структурних складових протидії фінансовій кризі.

Методика. У дослідженні автори застосовували метод імітаційного моделювання, що дозволив виявити кілька сценаріїв, які можуть бути здійснені при формуванні страхових фондів за різного покриття з боку компаній гірничо-металургійного комплексу. Додатково використана методика побудови методу дерев, що передбачає багатоваріантність формування страхового покриття в залежності від імовірності настання певних подій.

Результати. У роботі реалізовано порівняльний аналіз моделей банкрутства й забезпечення фінансової стійкості підприємства для цілей контролю якості виробленої продукції. Авторами статті розроблена модель, що може служити основою для формування інтелектуального процесу прийняття рішень за постійного рівня ризику. У роботі вказується, що основний фактор виникнення ризикових умов - зниження витрат на забезпечення безпеки виробничих процесів, що в умовах підприємств гірничо-металургійного комплексу породжує вторинний ризик.

Наукова новизна. $\mathcal{E}$ в тому, що безпека виробничого процесу визначена в залежності від того, наскільки значними повинні бути фінансові запаси підприємства для покриття можливих збитків і, відповідно, виникнення ситуації, коли фінансування підприємства вимагатиме додаткового фінансового потоку. У цій ситуації можуть бути використані поточні грошові потоки підприємства та враховані особливості зниження витрат на забезпечення безпеки виробничого процесу. У роботі даний аспект визначається як імовірнісний. Моделювання фінансової стійкості проводиться з урахуванням фактора забезпечення належного рівня безпеки виробничого процесу.

Практична значимість. Отримані дані дозволяють прогнозувати виплати не тільки зі страхових фондів підприємств, але також і з інших джерел, що зачіпають імовірність банкрутства або погіршення фінансового стану підприємства.

Ключові слова: страхові фонди, виробничі витрати, фiнансова стійкість, фінансова криза, безпека виробничого процесу

\section{Стратификация расходов страховых фондов на покрытие рисковых ситуаций производственного процесса}

\section{А. И. Полукаров ${ }^{1}$, Н. А. Праховник ${ }^{1}$, Ю. А. Полукаров ${ }^{1}$,} О. Е. Кружилко, Г. В. Демчук ${ }^{1}$

1 - Национальный технический университет Украины «Киевский политехнический институт имени Игоря Сикорского», г. Киев, Украина, e-mail: polukarov@kpi.com.de 2 - Государственное учреждение «Национальный научно-исследовательский институт промышленной безопасности и охраны труда», г. Киев, Украина

Цель. Оценка порядка формирования страховых фондов, которые могут применяться для решения проблем и покрытия структурных составляющих противодействия финансовому кризису.

Методика. В исследовании авторы применяли метод имитационного моделирования, который позволил выявить несколько сценариев, которые могут быть осуществлены при формировании страховых фондов при различном покрытии со стороны компаний горно-металлургического комплекса. Дополнительно использована методика построения метода деревьев, которая предполагает многовариантность формирования страхового покрытия в зависимости от вероятности наступления определенных событий.

Результаты. В работе реализован сравнительный анализ моделей банкротства и обеспечения финансовой устойчивости предприятия для целей контроля качества производимой продукции. Авторами статьи разработана модель, которая может служить основой для формирования интеллектуального процесса принятия решений при постоянном уровне риска. В работе указывается, что основный фактор возникновения рисковых условий - снижение затрат на обеспечение безопасности производственных процессов, что в условиях предприятий горнометаллургического комплекса порождает вторичный риск.

Научная новизна. Состоит в том, что безопасность производственного процесса определена в зависимости от того, насколько значительными должны быть финансовые запасы предприятия для покрытия возможных убытков и, соответственно, возникновения ситуации, когда финансирование предприятия потребует дополнительного финансового потока. В этой ситуации могут быть использованы текущие денежные потоки предприятия и учтены особенности снижения затрат на обеспечение безопасности производственного процесса. В работе данный аспект определяется как вероятностный. Моделирование финансовой устойчивости проводится с учетом фактора обеспечения должного уровня безопасности производственного процесса.

Практическая значимость. Полученные данные позволяют прогнозировать выплаты не только из страховых фондов предприятий, но также и из других источников, которые затрагивают вероятность банкротства или ухудшения финансового состояния предприятия.

Ключевые слова: страховые фонды, производственные расходы, финансовая устойчивость, финансовый кризис, безопасность производственного процесса

Recommended for publication by M.L. Rudakov, Doctor of Technical Sciences. The manuscript was submitted 15.10.19. 